\title{
Serum urea, creatinine and enzymatic activity of alkaline phosphatase in Nelore cattle raised in the Micro Upper Middle Gurguéia
}

\author{
Luana Araújo Saraiva ${ }^{1}$, Tairon Pannunzio Dias e Silva ${ }^{2,}$, , Patrick Elvis Paraguaio ${ }^{1}$, \\ Morgana Santos Araújo ${ }^{1}$, Sheila Vilarindo de Sousa ${ }^{1}$, Luciana Pereira Machado ${ }^{1}$ \\ ${ }^{1}$ University Federal of Piauí, Campus Professora Cinobelina Elvas, Bom Jesus, Piauí, Brazil \\ ${ }^{2}$ Center for Nuclear Energy in Agriculture, Animal Nutrition Laboratory, University of São Paulo, Piracicaba, São Paulo, Brazil
}

\section{Email address:}

tairon.mvet@gmail.com (T. P. D. Silva)

\section{To cite this article:}

Luana Araújo Saraiva, Tairon Pannunzio Dias e Silva, Patrick Elvis Paraguaio, Morgana Santos Araújo, Sheila Vilarindo de Sousa, Luciana Pereira Machado. Serum Urea, Creatinine and Enzymatic Activity of Alkaline Phosphatase in Nelore Cattle Raised in the Micro Upper Middle Gurguéia. Animal and Veterinary Sciences. Vol. 2, No. 4, 2014, pp. 105-108. doi: 10.11648/j.avs.20140204.14

\begin{abstract}
This study aimed to evaluate the influence of age and sex on serum concentrations of urea, creatinine and alkaline phosphatase and provide possible reference values for Nelore cattle raised in the micro region Upper Middle Gurguéia. Blood samples from 55 cattle, clinically healthy and reared in extensive system were randomly collected and examined. Treatments were formed according to the sex of animals ranging in age from 12 to 24 months: males ( $\mathrm{n}=13$ ) and female $(\mathrm{n}=27)$, and among females according to age: Group I, animals aged 0-12 months ( $\mathrm{n}=18)$ and Group II animals with 12 to 24 months $(n=27)$. All biochemical analyzes were performed in semi-automatic biochemical analyzer according to the colorimetric method. The gender factor was decisive and exerted influence $(p<0.05)$ on serum levels of urea, creatinine and alkaline phosphatase enzyme, with values within the reference, and the females were superior to urea and creatinine. When evaluated on the age variable, these blood parameters showed effect $(p<0.05)$ concentrations of urea and alkaline phosphatase, and the amounts of urea; females from 0.0 to 12 months were below benchmarks. Serum levels of urea, creatinine and enzymatic activity of alkaline phosphatase of cattle raised in the micro region Upper Middle Gurguéia are influenced by age and sex, their of determination specific region establishes parameters for better interpretation of research results, for a better interpretation of the parameters as well as to assist in the early diagnosis of possible diseases that may comprise the productive system.
\end{abstract}

Keywords: Age Factor, Clinical Biochemistry, Metabolites, Sex Factor

\section{Introduction}

The maximum productivity efficiency is the goal to be achieved, and three points are essential in a production system: genetics, health and nutrition. These factors have become intertwined and must be met in order to obtain better results [1]. Accordingly, the understanding of physiological and pathological changes of the various constituents of the blood is of great importance in the diagnosis and prognosis of diseases, especially metabolic characteristics that affect livestock and, consequently, trigger the low productivity of the herd.

Plasma creatinine is derived, almost in its entirety, from the catabolism of creatine in muscle tissue as energy in the form of phosphocreatine [2]. The presence of this metabolite in the circulation is a physiological factor, because that is one of the catabolite protein metabolisms. The creatinine excretion via the kidney is performed, and the plasma creatinine levels reflect the rate of renal filtration [3].

Urea has held its synthesis in the liver from ammonia due to the catabolism of amino acids and the recycling of ammonia in the rumen. Urea levels are analyzed in relation to the level of dietary protein and kidney function, and may be increased in cases of power failure due to impairment of rumen microbial nitrogen compounds in use for protein synthesis, increasing the amount of ammonia absorbed from the rumen $[2,4]$. 
Considered as enzyme induction, alkaline phosphatase (AP) is widely distributed in the body synthesized in the liver, osteoblasts, placental, intestinal and kidney epithelium, and the increased production of AP and its activity can be noted in the case of higher osteoblastic activity [5].

However, for a correct interpretation of metabolic profiles, it is essential to have appropriate reference values for the region and particular population [6]. Hence, it is extremely important to know the behavior of serum biochemical profiles according to age and sex.

There is no expressivity, in number, in the literature national about subject and, the same way, international most investigations focuses in dairy cattle [7, 8, 9, 10]. Few experiments have been developed for evaluation of animals to slaughter $[11,12]$. However, in the micro region Upper Middle Gurguéia there is no research to better and further development of local livestock, it is necessary to establish regional parameters.

Given the above, we aimed to evaluate the influence of age and sex on serum concentrations of urea, creatinine and enzymatic activity of alkaline phosphatase in Nelore cattle raised in the in the micro region Upper Middle Gurguéia.

\section{Materials and Methods}

Blood samples, were randomly collected and examined, from 58 cattle, Nellore, clinically healthy, raised extensive system, under the same management conditions, both with health food, in four municipalities located on micro region Upper Middle Gurguéia (in the cities at Bom Jesus, Cristino Castro, Palmeira of Piauí and Redenção of Gurguéia), at an altitude of $277 \mathrm{~m}$ with a semiarid climate or Bsh, according to Köppen [13], and annual average rainfall of $900 \mathrm{~mm}$, with maximum and minimum temperatures 36 and $18{ }^{\circ} \mathrm{C}$, and humidity relative at 55 and $75 \%$ respectively. The rainy season extends from November to May [14]. In Gurguéia valley, beyond the chapadões has the pediplanation area, which has enormous productive potential with the use of aquifers for large flows. The rainy season extends from October to May and the wettest months are November to March [15].

Treatments were formed according to the sex of animals ranging in age from 12 to 24 months: males $(n=13)$ and female $(\mathrm{n}=27)$, and among females according to age: Group
I, animals aged 0-12 months $(\mathrm{n}=18)$ and Group II animals with 12 to 24 months $(n=27)$.

Blood samples were collected by jugular venipuncture without excessive tying the artery using Vacutainer ${ }^{\circledR}$ system in siliconized tubes with $5 \mathrm{ml}$ capacity and the blood with standard needles ( $25 \times 0.8 \mathrm{~mm})$. After sampling, the samples were kept at room temperature to promote the formation and clot retraction; after the retraction of the clot, the tubes were centrifuged for 10 minutes at $3000 \mathrm{rpm}$. This procedure was performed in the local harvest in a way to avoid the hemolysis of the sample. Afterwards, the serum was separated by suction aliquoted and placed in plastic tubes with lid $\left(\right.$ Eppendorf $\left.^{\circledR}\right)$ kept under refrigeration for up to six hours and frozen at $-20{ }^{\circ} \mathrm{C}$ to perform later the biochemical tests.

All biochemical analyzes were performed in semi-automatic biochemical analyzer (Espectrum BS - 001 000 013), using commercial kits Labtest ${ }^{\circledR}$. The determination of blood urea nitrogen was performed according to the colorimetric method (urease - Labtest ${ }^{\circledR}$ ) at a wavelength of 580 to $620 \mathrm{~nm}$, the creatinine according to the colorimetric method (alkaline picrate - Jaffe) with 510nm wavelength and alkaline phosphatase according to the colorimetric method (modified Roy) at a wavelength of 590 $\mathrm{nm}$. All biochemical reactions were processed at $37{ }^{\circ} \mathrm{C}$ according to the instructions of the manufacturers.

Statistical evaluation of the results was performed using the methods recommended by the "Statistical Analysis System" [16], and using the Tukey test for comparison between means, at a significance level of $5 \%$ probability.

\section{Results and Discussion}

The results allow us to report that the gender factor was decisive and exerted influence $(\mathrm{p}<0.05)$ on serum levels of urea, creatinine and alkaline phosphatase enzyme (Table 1).

Serum creatinine values obtained in male animals, Nelore, raised in the State of Piauí differed significantly $(p<0.05)$ from those obtained in females of the same genetic group. Such result contrasts with data from [3], reporting that serum creatinine does not suffer influence of sex factors, a consequence of being a non- protein nitrogenous substance, formed from the metabolism of muscle creatine and phosphocreatine and not being influenced in their formation, either by diet or by protein catabolism.

Table 1. Influence of gender on the levels of s rum urea, creatinine and alkaline phosphatase in Nelore cattle raised in the micro region Upper Middle Gurguéia

\begin{tabular}{|c|c|c|c|}
\hline \multicolumn{4}{|c|}{ Sex } \\
\hline Parameters & Males $(n=13)$ & Females $(n=27)$ & Reference values $* *$ \\
\hline A. Phosphatase & $104.10 \pm 34.6^{\mathrm{a}}$ & $33.33 \pm 11.2^{\mathrm{b}}$ & 0.00 to $488.0 \mathrm{U} / \mathrm{L}$ \\
\hline Urea & $16.42 \pm 2.56^{\mathrm{b}}$ & $26.68 \pm 14.9^{\mathrm{a}}$ & 20.00 to $30.00 \mathrm{mg} / \mathrm{dL}$ \\
\hline Creatinine & $1.44 \pm 0.18^{\mathrm{b}}$ & $1.85 \pm 0.42^{\mathrm{a}}$ & 1.00 to $2.00 \mathrm{mg} / \mathrm{dL}$ \\
\hline
\end{tabular}

*Lowercase letters in the same rows do not differ by Tukey's test at $5 \%$ probability. ** [17]

The serum levels of urea outlined for the evaluation of influence of sex factors among experimental groups were found, from the results obtained in mice, to be significantly $(p<0.05)$ higher than those for males. This assessment 
allows us to state that the serum levels of urea in the male Nelore cattle evaluated in the study area are altered by sex and were below the reference values cited by [17].

It is known that feeding management influences on serum urea [18], and in protein deficiency in the diet of ruminants, ammonia concentrations are relatively low and the proportion of nitrogen recycled back to the rumen and urea is increased, thereby reducing the amounts of plasma urea nitrogen [17].

The parameters of alkaline phosphatase differed $(\mathrm{p}<0.05)$ between groups, and male animals had higher values, with a range of $70.77 \mathrm{U} / \mathrm{L}$. As for the normal standard range of 0.0 to $488 \mathrm{U} / \mathrm{L}$, no animal showed changes in normal values by [17].

Assessing the levels of serum creatinine in relation to age factor (Table 2), those showed no differences $(p>0.05)$ and were inversely related, with advancing age led to a tendency to decreased concentrations of this metabolite, with values of $1.85 \pm 0.41$ and $1.71 \pm 0.42 \mathrm{mg} / \mathrm{dL}$ for ages $0-12$ and 12-24 months, respectively.

Table 2. Influence of age on serum urea, creatinine and alkaline phosphatase in Nelore females bred in the Gurguéia Valley

\begin{tabular}{cccc}
\hline & \multicolumn{3}{c}{ Age } \\
\hline Parameters & $\mathbf{0 . 0 - 1 2}$ months (n=18) & 12-24 months (n=27) & Reference values** \\
\hline A. Phosphatase & $47.32 \pm 22.90^{\mathrm{a}}$ & $33.33 \pm 11.2^{\mathrm{b}}$ & 0.00 to $488.0 \mathrm{U} / \mathrm{L}$ \\
Urea & $15.99 \pm 16.38^{\mathrm{b}}$ & $26.68 \pm 14.9^{\mathrm{a}}$ & 20.00 to $30.00 \mathrm{mg} / \mathrm{dL}$ \\
Creatinine & $1.85 \pm 0.41^{\mathrm{a}}$ & $1.71 \pm 0.42^{\mathrm{a}}$ & 1.00 to $2.00 \mathrm{mg} / \mathrm{dL}$ \\
\hline
\end{tabular}

*Lowercase letters in the same rows do not differ by Tukey's test at 5\% probability. ** [17]

These results partially agree with [3], evaluating the influence of age on reference values of serum levels of urea and creatinine from Jersey cows rose in the State of São Paulo, who described that with advancing age there was a significant increase in the levels of these metabolites. However, the results found in our study corroborate with [19]. Given the divergence of this information, the determination of these parameters is essential for the region's Gurguéia valley, providing data to reference, especially, by to the present study was conducted with animals that are inserted, predominant, into the production system the region, as well as in northeastern Brazil. Where, in this type of zootechnical exploration, several factors that influence and consequently promote variation in concentrations of this metabolite, and the physiological adaptability to characteristics may impose conditions that vary between regions with values among the reference standards for the kind, according to [17].

Regarding the serum levels of urea, there was a significant increase $(\mathrm{p}<0.05)$ between the ages, a result that corroborates with [18], who report variations due to age and diet where the animals are subjected, with superiority to females aged between 12 and 24 months. However, for the group of females under 12 months of age, we observed serum levels below the reference values $[17,29]$, which may be a result of many factors that act on the variation of their concentrations as race, sex, physiological state beyond the management to which these animals are subjected [17]. However, one should always seek joint evaluation between these metabolites, for a greater reliability on the energy and protein metabolism of these animals [21]. It can be assumed that the dry cows from one to two years of age raised in the region of the Gurguéia Valley have serum values within the normal according to [17].

Evaluating and comparing the values of the enzyme phosphatase in the animals of the present study with the reference values proposed by [17], this biochemical element remained within the limits cited by the authors, differing $(p<0.05)$ between ages, corroborating with [22], and the animals belonging to the age group of up to 12 months showed higher values. This higher serum concentration in younger animals may be associated with increased osteoblastic activity determining a higher cell proliferation and deposition of calcium salts establishing the architecture and functionality of the tissue that is in heavy development [23].

Evaluation of different ages for males and formation of an initial reference parameter for this factor was not possible to be performed in this study because a small amount of male animals, which characterize the beef cattle, fact that it is associated with lack of technical knowledge on the part of producers who opt for a herd of low productivity and traditional and lack of fiscal incentives. Fact that contributes to the region Northeast is the less slaughter animals (10.2\%) in Brazil [24].

\section{Conclusions}

Serum levels of urea, creatinine and enzymatic activity of alkaline phosphatase of cattle raised in the micro region Upper Middle Gurguéia are influenced by age and sex, their of determination specific region establishes parameters for better interpretation of research results, for a better interpretation of the parameters as well as to assist in the early diagnosis of possible diseases that may comprise the productive system.

\section{References}

[1] Silva, N. V.; Costa, R. G. and Freitas, C. R. G. Alimentação de ovinos em regiões semiáridas do Brasil. Acta Veterinária Brasílica, 4, 233-241, 2010.

[2] González, F. H. D; Silva, S. C. Introdução a bioquímica clínica veterinária. 2 ed. Porto Alegre: Editora da UFRGS, 2006. $358 \mathrm{p}$. 
[3] Gregory, L.; Birgel Junior, E. H. and D’angelino, F. J. Valores de referência dos teores séricos da uréia e creatinina em bovinos da raça Jersey criados no Estado de São Paulo. Influência dos fatores etários, sexuais e da infecção pelo vírus da leucose dos bovinos. Arquivos do Instituto Biológico, 71, 39- 345, 2004.

[4] Berchielli, T. T.; Vega-Garcia, A. and Oliveira, S. G Principais técnicas de avaliação aplicadas em estudo de nutrição. In: Berchielli, T. T.; Pires, A.V.; Oliveira, S. G. (Eds). Nutrição de Ruminantes. 2 ed. Jaboticabal: Funep, 2011. p.565-600.

[5] Thrall, M. A.; Baker, D. C. and Campbell, T. W. Hematologia e Bioquímica Clínica Veterinária. São Paulo: Roca, 2007. $582 \mathrm{p}$

[6] Benesi, F. J.; Leal, M. L. R.; Lisbôa, J. A. N. et al. Parâmetros bioquímicos para avaliação da função hepática em bezerras sadias, da raça holandesa, no primeiro mês de vida. Ciência Rural, 33, 311-317, 2003.

[7] Fagliari, J. J.; Oliveira, E. C. and Pegorer, M. F. Relação entre o nível sérico de gamaglobulinas e as atividades de gama glutamiltransferase, fosfatase alcalina e aspartato aminotransferase de bezerros recém-nascidos. Arquivo Brasileiro de Medicina Veterinária e Zootecnia, 48, 105-112, 1996.

[8] Moraes, M. P.; Weiblen, R. and Silva, A. M. Evolução da imunidade passiva em fêmeas bovinas da raça Holandesa. Ciência Rural, 27, 435-40, 1997.

[9] Feitosa, F. L. F. Birgel, E. H. and Mirandola, R. M. S. Diagnóstico de falha de transferência de imunidade passiva em bezerros através da determinação de proteína total e de suas frações eletroforéticas, imunoglobulinas $\mathrm{G}$ e $\mathrm{M}$ e da atividade da gama glutamiltransferase no soro sanguíneo. Ciência Rural, 31, 251-255, 2001.

[10] Paulleti, P.; Machado Neto, R. and Packer, I. U. Quality of colostral passive immunity and pattern of serum protein fluctuation in newborn calves. Scientia Agricola, 60, 433-456, 2003.

[11] González, F. H. D.; Conceição, T. R., Siqueira, A. J. S. and LA Rosa, V. L. Variações sangüíneas de uréia, creatinina, albumina e fósforo em bovinos de corte no Rio Grande do Sul A Hora Veterinária, 20, 59-62, 2000.

[12] Rennó, L. N.; Valadares, R. F. D. and Valadares Filho, S. C. Concentração Plasmática de Uréia e Excreções de Uréia e Creatinina em Novilhos. Revista brasileira de zootecnia, 29, 1235-1243, 2000.
[13] Brasil. Secretaria Nacional de Irrigação. Departamento Nacional de Meteorologia. Normas climatológicas: 1961-1990. Brasília: EMBRAPA-SPI, 1992. 84 p.

[14] Aguiar, R. B. and Gomes, J. R. C. Projeto Cadastro de Fontes de Abastecimento por Agua Subterrânea Estado do Piauí, diagnóstico do Município de Bom Jesus. Fortaleza, 2004.

[15] Vieira, V. C. B.; Salviano, A. A. C. and Costa, E. F. Mapeamento de áreas degradadas na região do cerrado do Sul do Piauí. Fortaleza. Convênio Fundação Agente/CODEVASF, 2007. 75p.

[16] SAS (Statistical Analysis System). 2003. User's Guide. Cary, NC, SAS Institute Inc. $129 \mathrm{p}$.

[17] Kaneco, J. J.; Harvey, J. W. and Bruss, M. L. Clinical biochemistry of Domestic animal. 6 ed. San Diego: Academic Press, 2008. 918p.

[18] Benesi, F. J.; Coelho, C. S. and Leal, M. L. R. Parâmetros bioquímicos para avaliação da função renal e do equilíbrio hidroeletrolítico em bezerras sadias, da raça Holandesa, no primeiro mês de vida. Brazilian Journal Veterinary Research Animal Science, 42, 291-298, 2005.

[19] Feitosa, F. L. F.; Mendes, L. C. N. and Peiró, J. R. Influência da faixa etária nos valores de enzimas hepáticas e de ureia e creatinina em bezerros holandeses do nascimento até os 365 dias de vida. Ciência veterinária nos trópicos, 10, 54-61, 2007.

[20] Minafra, C. S.; Marques, S. F. F. and Stringhini, J. H. Perfil bioquímico do soro de frangos de corte alimentados com dieta suplementada com alfaamilase de Cryptococcus flavus e Aspergillus níger HM2003. Revista Brasileira de Zootecnia, 39, 2691-2696, 2010.

[21] González, F. H. D. and Campos, R. O leite como indicador metabólico-nutricional em vacas. A Hora Veterinária, 2, 36-38, 2003.

[22] Gasparelli, E.; Camargo, D. G. and Yanaka, R. Influência do tipo de parto nos valores das enzimas hepáticas e de uréia e creatinina de bezerros Nelore oriundos de fertilização in vitro (FIV) ao nascimento e às 24 horas de vida. Veterinária e Zootecnia, 15, 360-369, 2008.

[23] Doblaré, M.; Garci, J. M. and Goméz, M. J. Modelling bonne tissue fracture and heling a review. Engineering Fracture Mechanics, 71, 1809-1840, 2004.

[24] IBGE. 2012. Instituto Brasileiro de Geografia e Estatística. Estatística da Produção Pecuária. IBGE, Rio de Janeiro, Brasil. p.1-34. 